BeAta TopiJ-STEMPiŃSKa

Akademia Ignatianum w Krakowie

\title{
W TROSCE O MŁODZIEŻ. STANISŁAW PODOLEŃSKI SJ, PEDAGOG (NIE)ZNANY
}

\author{
„Młodzież i sprawy, \\ związane z jej wychowaniem, \\ stanowiły zawsze przedmiot \\ szczególnego zainteresowania i troski. \\ Rodzina i społeczeństwo, \\ naród i państwo \\ widziały przecież w niej \\ swą nadzieję i przyszłość". \\ Stanisław Podoleński (1930)
}

Abstrakt: Troska o harmonijne wychowanie młodych pokoleń jest wpisana w działalność wychowawczą podejmowaną przez wiele środowisk, zaczynając od rodziny, szkoły, przez państwo i Kościół. W II Rzeczypospolitej wszystkie te środowiska podjęły dyskusję nad właściwym kierunkiem wychowania przyszłych pokoleń. Jednym z priorytetowych zadań była troska o właściwe wychowanie zdrowotne i fizyczne młodzieży.

W dyskurs o istotnej roli edukacji prozdrowotnej włączył się jezuita Stanisław Podoleński. Problematyka podjęta w artykule dotyczy jego poglądów na istotę wychowania zdrowotnego i fizycznego jako wyraz troski o harmonijne wychowanie młodych w II Rzeczypospolitej.

Stanisława Podoleńskiego należy zaliczyć do grona aktywnych i zaangażowanych w działalność edukacyjną pedagogów w II Rzeczypospolitej. Bliskie mu były problemy młodych ludzi. W swoich publikacjach podkreślał, że istnieje nierozerwalny związek pomiędzy wychowaniem fizycznym i zdrowotnym a duchowym i intelektualnym człowieka. Jego zdaniem troska o harmonijny rozwój wszystkich sfer młodego człowieka jest podstawowym obowiązkiem rodziców, wychowawców, a nawet całego społeczeństwa.

Słowa kluczowe: Stanisław Podoleński, wychowanie fizyczne, wychowanie zdrowotne, II Rzeczypospolita, jezuici, młodzież, dzieci 
Po odzyskaniu niepodległości w 1918 roku Polacy musieli podjąć trud odbudowy kraju ze zniszczeń wojennych, zadbać nie tylko o poprawę sytuacji społeczno-ekonomicznej, lecz także o kształt i jakość edukacji oraz wychowania młodych pokoleń Polaków. W II Rzeczypospolitej nastąpił zauważalny rozwój pedagogiki. Powstały pierwsze ośrodki zajmujące się badaniami nad istotą wychowania i liczne koncepcje pedagogiczne - wśród nich można wskazać te dotyczące problematyki zdrowia i wychowania fizycznego młodych. Troska o integralny rozwój młodego pokolenia była również dostrzegalna w propagowaniu koncepcji wychowania fizycznego. „Stąd też szeroki obszar wspólnego działania w zakresie tworzenia koncepcji i ich realizacji zarówno środowiska pedagogicznego, jak i medycznego na rzecz wychowania zdrowego, silnego i pożytecznego obywatela" (Szczepańska 2014, s. 10). Do czołowych prekursorów tej dziedziny w II Rzeczypospolitej należy zaliczyć: Eugeniusza Piaseckiego, Zarys teorii wychowania fizycznego (1935); Stanisława Kopczyńskiego, Hygiena szkolna i wychowanie fizyczne w szkołach Rzeczypospolitej: (sprawozdanie za rok 1924 i 1925) (1927) i Zdrowie dziatwy szkót powszechnych w Polsce (1929). Nie tylko środowisko pedagogów, lekarzy, społeczników angażowało się w uświadomienie społeczeństwu znaczenia zdrowia i wychowania fizycznego w prawidłowym rozwoju młodzieży, również ówczesne władze były zainteresowane podnoszeniem poziomu świadomości społeczeństwa polskiego $\mathrm{w}$ temacie wychowania zdrowotnego i fizycznego dzieci i młodzieży. I tak, już w 1919 roku przy Ministerstwie Wyznań Religijnych i Oświecenia Publicznego powołano Wydział Higieny Szkolnej i Wychowania Fizycznego, a w Ministerstwie Zdrowia Publicznego Referat Wychowania Fizycznego wraz z Radą do spraw Wychowania Fizycznego i Kultury Cielesnej. Do zadań tych rządowych agend należało między innymi opiniowanie i doradzanie w sprawach wychowania fizycznego, sportu i zdrowia, a także „dążenie do ugruntowania pozycji wychowania fizycznego w tworzących się programach szkolnych" (Małolepszy 2005, s. 58).

Troska o odpowiedni poziom kształcenia i wychowania młodzieży, również w zakresie edukacji prozdrowotnej, była udziałem wielu środowisk. W tym okresie również Kościół katolicki oraz środowiska katolickie włączyły się aktywnie $\mathrm{w}$ dyskusję nad istotą wychowania zdrowotnego i fizycznego. Warto wymienić np.: Henryk Weryński, Bezdroża wychowania (1936); Leopold Chomski, Wychowanie fizyczne a etyka (1927); Mieczysław Kuznowicz, Zasady organizacji pracy społecznej nad młodzieżą; Fałszywa zwrotnica (1934).

Jednym z czołowych przedstawicieli był jednak Stanisław Podoleński SJ, znany publicysta i pedagog w II Rzeczypospolitej, współcześnie prawie zapomniany. W swoich publikacjach zwracał uwagę między innymi na istotne problemy zdrowotne dzieci i młodzieży. Osobę jezuity w ostatnich latach przypomniała Janina Kostkiewicz. Badaczka podkreśliła zasługi Podoleńskiego na polu troski o rodzinę. 
W artykule poświęconym poglądom na wychowanie prorodzinne Stanisława Podoleńskiego zaznaczyła, iż interesował się problematyką rodziny, zwracał uwagę na jej kondycję społeczną, ekonomiczną, zdrowotną oraz wychowawczą (Kostkiewicz 2012). W opublikowanej w 2013 roku rozprawie o kierunkach i koncepcjach pedagogiki katolickiej w Polsce 1918-1939 przypomniała o doniosłym wkładzie jezuity w dyskusję dotyczącą troski o integralne wychowanie ówczesnego młodego pokolenia (Kostkiewicz 2013).

Celem artykułu jest przypomnienie postaci Stanisława Podoleńskiego i przybliżenie jego poglądów dotyczących istoty wychowania zdrowotnego i fizycznego w integralnym rozwoju młodego człowieka. Przyjęcie takiego celu podyktowane jest faktem, iż niewątpliwie to poglądy Stanisława Podoleńskiego należy uznać za reprezentatywne dla środowiska katolickiego. Ponadto niewielu współczesnych badaczy zajmowało się problemem wychowania zdrowotnego czy fizycznego w II Rzeczypospolitej, chociaż w ostatnich latach powstały prace, których autorzy ukazali osiągnięcia polskiej myśli i praktyki w zakresie wychowania zdrowotnego i fizycznego (Demel 2000; Szczepańska 2014; Szymański 1995; Wasztyl 2002). Oprócz tego z analizy literatury wynika, iż S. Podoleński był zainteresowany stanem zdrowotnym i wychowaniem fizycznym dzieci i młodzieży i dał temu wyraz nie tylko w publikacjach wprost odnoszących się do tej problematyki, ale chętnie poruszał ten wątek „w większych pracach $\mathrm{z}$ dziedziny wychowania moralnego lub wychowania społecznego w organizacjach młodzieżowych" (Kostkiewicz 2013, s. 246). W takiej sytuacji zasadne wydają się pytania: Jak S. Podoleński wyrażał troskę o wychowanie młodzieży ze szczególnym uwzględnieniem wychowania zdrowotnego i fizycznego w swojej twórczości pedagogicznej? Wobec powyższego: Czy można uznać, że poglądy jezuity nie straciły na aktualności? Zanim przejdę do odpowiedzi na powyższe pytania, przedstawię krótki biogram S. Podoleńskiego.

\section{SYLWETKA STANISŁAWA PODOLEŃSKIEGO - JEZUITY, PUBLICYSTY I PEDAGOGA}

Stanisław Podoleński urodził się 2 grudnia 1887 r. w Bihaču w Bośni jako syn Jana i Bronisławy z Wagnerów. Jego ojciec był urzędnikiem państwowym. W wieku 10 lat rozpoczął naukę w krakowskim gimnazjum św. Anny, gdzie w 1905 roku zdał maturę. W tymże roku S. Podoleński wstąpił do zakonu jezuitów, a po 10 latach otrzymał święcenia kapłańskie. Po ukończonych studiach zakonnych - filozofii i teologii, S. Podoleński przez rok był również studentem Uniwersytetu Jagiellońskiego (1916-1917). Pierwsze doświadczenie w zawodzie pedagoga (nauczyciela i wychowawcy) S. Podoleński zdobył w Gimnazjum Jezuitów w Chyrowie, uczył 
tam języka łacińskiego, polskiego, niemieckiego i historii naturalnej (1909-1912) (ATJKr, rkp 2022, 1177, 1927, 1524). Od 1918 roku (po odbyciu studiów z duchowości jezuickiej) związał się z „Przeglądem Powszechnym”' (Jakubowski 1987). W periodyku był odpowiedzialny między innymi za dział pedagogiczny. Ponadto redagował dział etyki indywidualnej i medyczny. Jego działalność społeczno-pedagogiczna nie ograniczała się jedynie do publikacji, aktywnie uczestniczył w spotkaniach i konferencjach dotyczących tematów społeczno-etycznych. Ponadto był zaangażowany w opiekę nad rodziną na terenie Krakowa. Wygłaszał rekolekcje, opiekował się młodzieżą w szkole powszechnej i gimnazjum żeńskim oraz otaczał opieką duszpasterską chorych w szpitalu św. Ludwika. Jego dorobek publicystyczny stanowi 13 książek i broszur oraz ok. 200 artykułów w czasopismach i ok. 200 recenzji z zakresu spraw etyczno-społecznych, małżeństwa, rodziny, szkoły, państwa (Grzebień 1983, s. 138-139). Pozostawioną spuściznę pedagogiczną S. Podoleńskiego można podzielić na prace o charakterze naukowym i popularno-naukowym. Należy jednak zaznaczyć, jak pisał J. Kostkiewicz, że ten drugi rodzaj pisarstwa ma zdecydowanie wychowawczy charakter, „co oznacza, że składające się nań prace są pisane w celu wychowawczego oddziaływania na młodzież" (Kostkiewicz 2013, s. 300), a ich adresatem była zarówno młodzież, jak i rodzice oraz wychowawcy. W 1939 roku wraz $\mathrm{z}$ innymi jezuitami został aresztowany, następnie przetrzymywano go w więzieniu przy ul. Montelupich, w obozie pracy w Wiśniczu oraz w obozach koncentracyjnych w Oświęcimiu i Dachau. Zmarł na kilka miesięcy przed zakończeniem II wojny światowej 13 stycznia 1945 roku (Grzebień 1983, 1993; Hajduk 2003; Cieślak 2009).

\section{TROSKA O WYCHOWANIE MŁODZIEŻY - POGLĄDY STANISŁAWA PODOLEŃSKIEGO}

Janina Kostkiewicz w rozprawie Kierunki i koncepcje pedagogiki katolickiej w Polsce 1918-1939 stwierdziła, że „spuścizna naukowa S. Podoleńskiego w swej zasadniczej wymowie kieruje się ku personalizmowi” (Kostkiewicz 2013, s. 399), ale nieobojętne mu były problemy społeczne i wychowawcze społeczeństwa w II Rzeczypospolitej. Stanisław Podoleński należał bowiem do tej grupy osób, którym zależało na odpowiednim wychowaniu młodzieży i dał temu wyraz między innymi w monografii

\footnotetext{
1 „Przegląd Powszechny” został założony w 1884 roku przez polskiego jezuitę Mariana Morawskiego. Podstawowym celem periodyku było szerzenie zasad katolickich wśród inteligencji oraz refleksja nad zagadnieniami dotyczącymi życia społecznego, naukowego czy literackiego. Na łamach czasopisma zamieszczano artykuły z takich dziedzin, jak: pedagogika, socjologia, psychologia, literatura, historia, filozofia, teologia, religioznawstwo, etyka społeczna. Na łamach czasopisma poruszano bieżące sprawy dotyczące polityki państwa (Jakubowski 1987).
} 
Podręcznik pedagogiczny. Wskazówki dla rodziców i wychowawców (Podoleński 1930a), we wstępnie którego zaznaczył, iż „wychowanie jest sztuką, którą trzeba znać i umieć się nią posługiwać, do której nie wystarczą same dobre chęci” (Podoleński 1930a, s. 5), ponieważ wychowanie ma pomóc młodym przygotować się do życia i „ustrzec młodzież przed grożącymi jej zewsząd niebezpieczeństwami” (Podoleński 1930a, s. 5). S. Podoleński ze swoją koncepcją wychowania wpisywał się nie tylko w kierunek pedagogiki katolickiej, lecz także w nowe koncepcje wychowania i kształcenia dziecka, dynamicznie rozwijające się wówczas w Europie. Jezuita podkreślił, iż wychowanie „obejmuje” całego człowieka, zatem w procesie wychowania należy dbać o harmonijny rozwój wszystkich sfer człowieka. Dla S. Podoleńskiego wychowawca musi posiadać „umiejętność i dar wychowania” - wynikające z odpowiedniego wykształcenia oraz cech osobowościowych, to on bowiem musi rozumieć dziecko i „wnikać w jego duszę i potrzeby” (Podoleński 1930a, s. 21). Stał na stanowisku, że to rodzina ma niepodważalne prawo do wychowania własnych dzieci i nikt tego prawa odebrać jej nie może (Podoleński 1917; Kostkiewicz 2012; Okrasa 2015). Społeczeństwo i instytucje, takie jak Kościół, szkoła i państwo, powinny wspierać rodzinę w wychowaniu, a zastąpić ją mogą, a nawet powinny, tylko wtedy, gdy rodzina jest niewydolna wychowawczo.

Istotne dla S. Podoleńskiego było wychowanie społeczno-moralne młodych ludzi. Z całą stanowczością podkreślał, że młodzi są przyszłością narodu, dlatego właśnie trzeba otoczyć ich właściwą opieką i troską. Twierdził, że: „Młodzież, zawsze wszystkim droga, dziś stała się nią podwójnie - zarówno ze względu na wielkość zadań, jakie ją czekają, jak i dlatego że nie przekazujemy jej dziedzictwa, które mogłaby objąć w spokojne posiadanie, ale czekają ją warunki trudne, wchodzi w życie, które na szereg jeszcze lat nie będzie zasłane różami" (Podoleński 1930b, s. 32). S. Podoleński dostrzegł, że po zakończeniu I wojny światowej młodzież wymagała szczególnej opieki, gdyż w warunkach wojennych: „Wśród brudu moralnego i braku najpotrzebniejszych nieraz środków utrzymania, wśród ogólnego wyczerpania i przygnębienia, spowodowanego przedłużaniem się wojny, wzrastała [...] młodzież, która w chwili wybuchu wojny liczyła najwyżej pięć lat życia" (Podoleński 1930b, s. 36).

Stanisław Podoleński zaznaczył także, iż młodzież powojenna ma wiele zalet, jednak dorośli dostrzegają przede wszystkim jej wady, które często są wynikiem sytuacji życiowych i przeżyć, w obliczu których znaleźli się młodzi ludzie. Zatem ważnym zadaniem, jakie powinni postawić przed sobą dorośli, będzie wyeliminowanie niepożądanych zachowań polskiej młodzieży, które często były wynikiem niekorzystnego wpływu otoczenia. Dorośli, chcąc dobrze wywiązać się z nałożonych nań obowiązków względem dzieci i młodzieży, przede wszystkim powinni dążyć do poznania i zrozumienia przyczyn takich niewłaściwych zachowań 
młodych ludzi, a „roztropność musi kierować postępowaniem rodziców w całem wychowaniu" (Podoleński 1930b, s. 40). Podkreślił, że to trudny czas wojny ukształtował młode pokolenia i to pokolenie jest „pewne siebie”, „śmiałe” „aroganckie”, a także samodzielne i zaradne życiowo. Dostrzegł także, że: „Wprawdzie młodzież [...] występuje z większą swobodą, śmiałością i otwartością - co należy uważać za objaw dodatni - ale równocześnie jest ona bardziej nieustępliwa, mniej milczy, niełatwo przyjmuje zdanie starszych, domaga się wszędzie wolności, nie lubi przepisów, nie chce się ugiąć, staje się uparta i nieposłuszna" (Podoleński 1930b, s. 43).

Częściową winę za takie zachowania młodzieży ponoszą dorośli - „część winy spada na dom, część na szkołę, największa część na ogół, który nie umie i nie stara się stworzyć środowiska, sprzyjającego wychowaniu młodzieży" (Podoleński 1930b, s. 47). Dorośli zachowywali się niestosownie, często nie byli w stanie sprostać stawianym im wymaganiom, hołdowali „nieprzyzwoitym modom”, nie zgłaszali sprzeciwu wobec wszechobecnej w tamtym okresie prostytucji i pornografii. Zapomnieli o właściwych zasadach i to właśnie: „Dzięki takim stosunkom duża część młodzieży [...] wychowywała się od dziecka wśród lekceważenia poczucia przyzwoitości i skromności, oddychała atmosferą przesyconą wybujałym erotyzmem, oswajała się z nadużyciami i zbrodniami na tle seksualnym, słuchała drwin na temat wierności małżeńskiej" (Podoleński 1930b, s. 44). Oczywiście polskiej młodzieży w II RP można bardzo wiele zarzucić, jednak mimo wszystkich wad należy się jej troska i wskazanie właściwych drogowskazów i to ważne zadanie S. Podoleński wyznaczył społeczeństwu, które powinno się zrehabilitować, wcześniej bowiem nie zdało egzaminu $\mathrm{z}$ wychowania. Aby sytuacja uległa poprawie, niezbędne będzie wprowadzenie skuteczniejszych metod wychowawczych. S. Podoleński radził dorosłym, by słuchali młodych, starali się zrozumieć, iż oni mogą mieć własne plany na życie, marzenia, ale też przeżywają poważne rozterki duchowe, egzystencjalne i te „Zwykłe” uczuciowe. Ich świat jest również pełen sprzeczności, dylematów i wątpliwości. Dorośli mogą wspierać młodych, służyć radą, ale najpierw młodzi muszą im zaufać. Jak to osiągać? Okazaniem szacunku, zrozumienia i troski o młodzież. Jednak jak zaznaczył jezuita, „ogromną trudnością jest również znalezienie złotego środka pomiędzy zachowaniem autorytetu wychowawcy, a owym »stosunkiem przyjacielskim«" (Podoleński 1930b, s. 49).

\section{STANISŁAWA PODOLEŃSKIEGO SJ POGLĄDY NA WYCHOWANIE ZDROWOTNE I FIZYCZNE MŁODEGO POKOLENIA}

Stanisława Podoleńskiego interesowały problemy społeczne, które dotykały rodziny, dzieci, młodzieży, najogólniej społeczeństwa. Wypowiadał się na tematy związane 
z odpowiednim wychowaniem młodych do narzeczeństwa i małżeństwa, wychowaniem religijnym (Podoleński 1919; Podoleński 1938). Zabierał głos w tak ważkich sprawach społecznych, jak: aborcja, eutanazja itp. Wprowadzał czytelników „Przeglądu Powszechnego" w zawiłą problematykę prawną związaną z próbami legalizacji rozwodów w II Rzeczypospolitej. Zwracał uwagę społeczeństwa na konieczność troski nie tylko o zdrowie moralne młodych, lecz także o stan zdrowia młodzieży i wychowanie fizyczne młodego pokolenia. Przedstawiając poglądy S. Podoleńskiego dotyczące wychowania ciała, ukażę je w dwóch kategoriach, zgodnie z podziałem przyjętym przez jezuitę w podręczniku dla rodziców: pierwsza dotycząca troski o codzienne zdrowie młodego pokolenia, druga na temat wychowania fizycznego i sportu.

W części III Podręcznika pedagogicznego, pt. Wychowanie ciała, S. Podoleński zawarł postulaty, rady i wskazówki dotyczące troski o ciało w jego całokształcie. Przez pojęcie „wychowanie ciała” Podoleński rozumiał staranie o to, „aby dziecko wyrosło zdrowe, silne i stąd zdolne do wszelkiej pracy, zarówno fizycznej, jak i umysłowej, wytrzymałe na trudy i odporne przeciw chorobom, a zarazem aby w życiu moralnem, duchowem ciało było mu sprzymierzeńcem i pomocnikiem, a nie utrudnieniem i przeszkodą" (Podoleński 1930a, s. 61).

Radził rodzicom, aby pamiętali o najdrobniejszych i z pozoru najbłahszych sprawach, tj. o czystości i porządku w miejscu zamieszkania, właściwym pożywieniu i sposobie odżywiania oraz o właściwym czasie na „spoczynek i sen”, pielęgnowaniu wzroku i słuchu, hartowaniu i wzmacnianiu ciała. Dbałość o zapewnienie odpowiedniego miejsca i właściwych warunków do życia będzie sprzyjała harmonijnemu rozwojowi młodego pokolenia. To w pierwszej kolejności rodzice są odpowiedzialni za stan zdrowia dzieci. S. Podoleński dostrzegł związki między wychowaniem zdrowotnym a wychowaniem katolickim: „Do troski o ciało skłaniają nas wreszcie względy nadprzyrodzone [...]. Wiara katolicka poleca zatem dbać nie tylko o duszę, ale i o ciało [...]. W całokształcie wychowania troska o ciało - jego zdrowie i należyty rozwój - powinna zajmować ważne miejsce" (Podoleński 1930a, s. 62-63).

W działalności S. Podoleńskiego troska o stan zdrowotny młodzieży zajmowała również istotne miejsce. Według Ryszarda Rauby, S. Podoleński prowadził systematyczną obserwację stanu zdrowia ówczesnej młodzieży szkolnej (Rauba 2011). Efektem tej działalności był tekst poświęcony kondycji zdrowotnej młodzieży polskiej pt. Stan zdrowotny naszej młodzieży szkolnej (Podoleński 1937). Jezuita z ubolewaniem stwierdził, że pomimo poprawy sytuacji życiowej polskiego społeczeństwa, dostępu do właściwych produktów spożywczych, lepszej opieki nad matką i dzieckiem, podniesienia poziomu opieki zdrowotnej, stan zdrowia polskich dzieci nie był najlepszy. Badania przeprowadzone przez lekarzy wykazały, że „najliczniejsze oczywiście, zwłaszcza u młodszych, były [...] przejściowe 
niedomagania serca, towarzyszące takim chorobom, jak zapalenie płuc, błonica, płonica, choroby nerek, anemia" (Podoleński 1937). Przyczynami złego stanu zdrowia według jezuity są „nędza, kryzys gospodarczy, ciasnota i niedostateczna higiena mieszkań, brak odżywienia i odzieży, w szkole zaś przepełnienie klas i stąd złe powietrze i pył, brak boisk itd. Wszyscy umieją również na pamięć, że jak się podniesie ogólny stan gospodarczy, to i te niedomagania stopniowo znikną" (Rauba 2011). S. Podoleński podpowiadał, że najpierw należy znaleźć przyczyny, aby móc z nimi walczyć lub przynajmniej ograniczyć złe wpływy. Mieli się tym zająć lekarze szkolni, jednak wychowawcy i rodzice uczniów również mogą w tym względzie wiele zrobić. Ich uwagi i obserwacje mogą pomóc w przeciwdziałaniu takiemu stanowi rzeczy. Sam S. Podoleński sugerował, by zmniejszyć liczbę zajęć szkolnych i pozaszkolnych, co znacznie poprawiłoby kondycję psychiczną ucznia oraz korzystnie działałoby na jego serce.

Jezuita powrócił do zagadnień zdrowotnych także dwa lata później, w 1939 roku. Na łamach „Przeglądu Powszechnego” ukazał się jego artykuł Szkoła a zdrowie młodego pokolenia (Podoleński 1939). Z przeprowadzonych przez lekarzy badań wynikało, iż stan zdrowia młodzieży nie ulegał poprawie. Młodzież miała kłopoty zdrowotne związane z układem mięśniowym, stawowym i kostnym, zaburzenia układu krążenia. Powszechna była próchnica. Na taki stan rzeczy wpływ miały zaniedbania zarówno w środowisku rodzinnym, jak i szkolnym. „Zbyt duża liczba zajęć, stąd konieczność pracowania niekiedy w nocy, brak potrzebnego snu i odpoczynku (zwłaszcza u młodzieży dojeżdżającej) wpływają szkodliwie na zdrowie młodych i pozostawiają niekiedy trwałe tego ślady" (Podoleński 1939, s. 370). S. Podoleński zwrócił uwagę, że przyczyny tego mogą tkwić w „przeładowanych” programach szkolnych, źle prowadzonych zajęciach z wychowania fizycznego. Według jezuity, należałoby prowadzić działania profilaktyczne w zakresie wielu chorób pod kierunkiem lekarzy szkolnych na terenie szkoły. Postulat ten, wysuwany również przez inne osoby i środowiska, nie spotkał się z aprobatą władz. Przyczyna była prozaiczna - brak środków finansowych na podjęcie tego typu działalności profilaktycznej.

Jedną z przyczyn kłopotów ze zdrowiem młodzieży widziano w źle prowadzonych zajęciach z wychowania fizycznego. Dla S. Podoleńskiego również kwestie wychowania fizycznego były przedmiotem zainteresowań sprawami młodych. $\mathrm{Na}$ łamach „Przeglądu Powszechnego” w 1930 roku w artykule zatytułowanym Sport dzisiejszy a wychowanie fizyczne (Podoleński 1930c) podjął problem istotnej roli wychowania fizycznego i sportu w prawidłowym rozwoju młodzieży. S. Podoleński zauważył, że sport stał się bardzo atrakcyjny ze względu na m.in. jego widowiskowy charakter, ale także był traktowany, szczególnie po I wojnie światowej, jako swego rodzaju katharsis. Jezuita zauważył, że: „Ruch na wolnym powietrzu, 
swoboda i niewymuszona radość miały pokrzepić nadwątlony organizm, dać należyte wytchnienie po trudach, wlać zapał do nowej pracy, atmosfera zaś towarzyska, potęgując te uczucia i dając pole do szlachetnej rywalizacji, miała wzmocnić równocześnie węzły solidarności" (Podoleński 1930c, s. 293).

Jezuita przypominał, iż: „Troska o ciało musi być kierowana tą wyższą myślą, że czyniąc je zdrowym, silnym, sprawnym i pięknym, chce je uczynić tym podatniejszym narzędziem dla duszy, by pomagało człowiekowi w jego pracy dla siebie i dla drugich, dla Boga i ojczyzny" (Podoleński 1930c, s. 294).

Uważał, że to dzięki między innymi ćwiczeniom fizycznym człowiek uczy się samodyscypliny, systematyczności, opanowania, ale także pokory, przestrzegania zasad, współpracy i zdrowej rywalizacji. Jezuita dostrzegł także „ciemne” strony sportu, szczególnie sportu zawodowego. Nie widział pozytywnych stron w popisach sportowych, szczególnie w odniesieniu do dziewcząt. Sport, który uczy tylko rywalizacji, „przynosi więcej szkody niż pożytku”, naraża bowiem zdrowie, a nawet życie młodych (Podoleński 1931, s. 190; Kostkiewicz 2013). Jednak nie powinno się zaniedbywać ćwiczeń fizycznych i w szkołach należy prowadzić zajęcia z wychowania fizycznego, które mają służyć harmonijnemu rozwojowi „fizycznej i duchowej strony człowieka”, a „ćwicząc się fizycznie powinna młodzież mieć zawsze przed oczyma wyższe cele i uczyć się szacunku dla ciała” (Podoleński 1930a, s. 87).

Stanisław Podoleński twierdził, że najlepszą i naturalną formą aktywności dla młodzieży jest ruch na świeżym powietrzu. Troska o stan zdrowia i zapewnienie właściwego wychowania fizycznego młodych była jednym $z$ aspektów wychowania, na które uwagę społeczeństwa zwracał jezuita. Dla Podoleńskiego zagadnienia wychowania zdrowotnego i fizycznego były niezwykle istotne i traktował je jako nieodłączny element prawidłowego wychowania oraz harmonijnego rozwoju młodego pokolenia.

\section{PODSUMOWANIE}

Stanisława Podoleńskiego należy zaliczyć do grona aktywnych i zaangażowanych w działalność edukacyjną pedagogów w II Rzeczypospolitej. Bliskie mu były problemy młodych ludzi. Z troską pochylał się nad kwestiami edukacji intelektualnej, moralnej, społecznej i patriotycznej. Podkreślał rolę wychowania zdrowotnego i fizycznego w całokształcie procesu wychowania. W swoich publikacjach kładł nacisk na aktualne problemy, z którymi przyszło się zmierzyć młodemu pokoleniu. $Z$ mocą podkreślał, iż młodzież potrzebuje wsparcia osób dorosłych, ale także jasno określonych granic, właściwych wzorców postępowania oraz co najistotniejsze mądrych i kochających rodziców i wychowawców. $Z$ całą stanowczością 
podkreślał, że dopiero: „Kiedy wychowanie fizyczne pomagać będzie duchowej, a moralne i religijne fizycznej stronie człowieka, wówczas dopiero będziemy mieli »ludzi«; w przeciwnym razie nie patrzmy lepiej w przyszłość" (Podoleński 1930c, s. 314). Jego zdaniem troska o prawidłowo prowadzone zajęcia z wychowania fizycznego powinna być udziałem również nauczycieli. To od ich postawy zależy stosunek młodych do własnego ciała, docenienie aktywności fizycznej czy szerzej całej kultury fizycznej. S. Podoleński był przeciwnikiem sportu wyczynowego i współzawodnictwa w sporcie. Twierdził, iż przynosi ono więcej szkody niż pożytku (Podoleński 1931). Stał na stanowisku, że kobietom nie przystoi brać udziału w zawodach sportowych. Był zwolennikiem odrębnych zajęć, a przede wszystkim programu, ćwiczeń dla dziewcząt. Uważał, że równolegle z wychowaniem fizycznym w prawidłowym rozwoju młodzieży ważne jest odpowiednie odżywianie, właściwa higiena, zapewnienie wolnego czasu i troska o dobry ogólny stan zdrowia. Można pokusić się o stwierdzenie, iż napisany i skierowany m.in. do rodziców podręcznik pedagogiczny może stanowić dowód na zaangażowanie S. Podoleńskiego w wychowanie młodego pokolenia.

Mimo upływu czasu, istotnych zmian w przyjętych metodach wychowania, stosunku rodziców i wychowawców do młodych ludzi problemy, na które zwracał uwagę S. Podoleński, nie zostały w wielu kwestiach rozwiązane. Nadal toczy się dyskusja dotycząca istoty wychowania zdrowotnego i fizycznego młodzieży, zagrożeń cywilizacyjnych, kształtowania prawidłowych nawyków żywieniowych i podejmowania aktywności fizycznej. Wiele problemów, na które zwracał uwagę S. Podoleński, zostało już rozwiązanych. Jednak troska o właściwie wychowanie młodzieży jest wciąż aktualnym zadaniem, wobec którego staje współczesne polskie społeczeństwo.

\section{LITERATURA}

ATJKr, Archiwum Prowincji Polski Południowej Towarzystwa Jezusowego w Krakowie: Stanisław Podoleński, Dokumenty osobiste członków TJ z lat 1920-1969, rkp nr 2022; Dokumenty osobiste, rkp nr 1177, rkp 1927; 1524.

Chomski L., 1927, Wychowanie fizyczne a etyka. „Miesięcznik Katechetyczny i Wychowawczy", t. 16, 259-266.

Cieślak S., 2009, Oblicza cierpienia i miłości. Słudzy Boży jezuici - męczennicy z II wojny światowej. Kraków, Wydawnictwo WAM.

Demel M., 2000, Z dziejów promocji zdrowia w Polsce, t. 1-2. Kraków, Akademia Wychowania Fizycznego im. Bronisława Czecha. 
Grzebień L., 1983, Podoleński Stanisław Tadeusz. W: Polski Słownik Biograficzny, t. XXVII, Wrocław-Warszawa-Kraków-Gdańsk-Łódź, Polska Akademia Nauki. Instytut Historii, 138-139.

Grzebień L., 1993, Podoleński Stanisław Tadeusz. W: L. Grzebień, Słownik jezuitów polskich: 1564-1990, t. 9, Kraków, Wydawnictwo WAM, 9.

Hajduk A., 2003, Podoleński Stanisław Tadeusz. W: R. Czekalski, Z. Marek, R. Murawski (red.), Słownik katechetyków polskich XX wieku. Warszawa, Wydawnictwo Salezjańskie, 203-204.

Jakubowski Z., 1987, Ideologia i polityka Kościoła Katolickiego w Polsce - ciagłość i zmiany. „Przegląd Powszechny” 1884-1985. Warszawa, Wydawnictwo ANS.

Kopczyński S., 1927, Hygiena szkolna i wychowanie fizyczne w szkołach Rzeczypospolitej: (sprawozdanie za rok 1924 i 1925). Warszawa, Druk. Kooperatywy Prac. Druk.

Kopczyński S., 1929, Zdrowie dziatwy szkół powszechnych w Polsce. Warszawa, Książnica-Atlas.

Kostkiewicz J., 2012, Wychowanie prorodzinne w myśli społeczno-pedagogicznej ks. Stanisława Podoleńskiego SJ (1887-1945). W: S. Cieślak, B. Topij-Stempińska (red.), Społeczeństwo, kultura, wychowanie w poglądach polskich jezuitów okresu II Rzeczypospolitej. Kraków, WAM, Akademia Ignatianum, 141-167.

Kostkiewicz J., 2013 Kierunki i koncepcje pedagogiki katolickiej w Polsce 1918-1939. Kraków, Wydawnictwo Impuls.

Kuznowicz M., 1934, Fałszywa zwrotnica. „Związkowiec”, nr 5-6, 3-6.

Małolepszy E., 2005, Polityka władz II Rzeczypospolitej wobec wychowania fizycznego i sportu na wsi. „Prace Naukowe Akademii im. Jana Długosza w Częstochowie Seria: Kultura Fizyczna”, z. VI, 57-65.

Okrasa M., 2015, Wskazówki dotyczące wychowania $w$ rodzinie prezentowane na łamach czasopism w XIX wieku, opublikowano: http://wwr.uni.wroc.pl/pl/articles_pl/Tom_002_Art_002_MARZENA_OKRASA.pdf [dostęp: 13.02.2016].

Piasecki E., 1935, Zarys teorji wychowania fizycznego. Lwów, Zakład Narodowy im. Ossolińskich.

Podoleński S., 1917, Pilnujemy wychowania. „Głosy Katolickie”, nr 199, 3-32.

Podoleński S., 1919, Wychowanie religijne w domu. „Głosy Katolickie”, nr 228-229, 1-31.

Podoleński S., 1930a, Podręcznik pedagogiczny. Wskazówki dla rodziców i wychowawców. Kraków, Wydawnictwo WAM.

Podoleński S., 1930b, Psychika dzisiejszej młodzieży. „Przegląd Powszechny”, t. 185, 32-52.

Podoleński S., 1930c, Sport dzisiejszy a wychowanie fizyczne. „Przegląd Powszechny”, t. 188, 292-314. 
Podoleński S., 1931, Zarys teorii wychowania fizycznego. „Przegląd Powszechny”, t. 190, 102-106.

Podoleński S., 1937, Stan zdrowotny naszej młodzieży szkolnej. „Przegląd Powszechny", t. 213, 176-194.

Podoleński S., 1938, U progu. Książka dla młodych. Kraków, Wydawnictwo WAM. Podoleński S., 1939, Szkoła a zdrowie młodego pokolenia. „Przegląd Powszechny”, t. 222, 363-374.

Rauba R., 2011, Jezuici i wychowanie młodzieży. Lewica.pl, opublikowano: http:// lewica.home.pl/?id=24119 [dostęp: 10.02.2016].

Szczepańska B., 2014, Higiena szkolna w szkolnictwie ogólnokształcacym w Drugiej

Rzeczypospolitej. Łódź, Wydawnictwo Uniwersytetu Łódzkiego.

Szymański L., 1995, Kultura fizyczna w polityce II Rzeczypospolitej. Wrocław, Wydawnictwo AWF.

Polska kultura fizyczna w czasach zaborów i Drugiej Rzeczypospolitej, 2002, R. Wasztyl (red.), Kraków, Akademia Wychowania Fizycznego im. B. Czecha.

Weryński H., 1936, Bezdroża wychowania. „Ruch Katolicki”, t. 6, 414-423.

\title{
OUT OF CONCERN FOR THE YOUTH. STANISŁAW PODOLEŃSKI SJ, AN (UN)KNOWN PEDAGOGUE
}

\begin{abstract}
The concern for harmonious education of young generations is present in the educational activity undertaken by many environments, from family, school, through the state and church. In the Second Polish Republic, all of these environments were engaged in the discussion what educational direction was appropriate for the future generations. One of the priority tasks was the concern for proper health and physical education of the youth.

Stanisław Podoleński, a Jesuit, joined the discourse about the role of health promoting education. The article presents Stanisław Podoleński's views concerning health, physical as well as sports education as an expression of his concern for the harmonious education of the youth in the Second Polish Republic.

Stanisław Podoleński should be included among pedagogues from the Second Polish Republic who were actively engaged in the educational work. Podoleński had a remarkable affinity for the problems of the youth. In his publications, he emphasised the fact that there is an inseparable connection between physical and health education as well as spiritual and intellectual education. In his view, the concern for the harmonious development of all the spheres of the young man is the main obligation of parents, teachers and even of the whole society.
\end{abstract}

Keywords: Stanisław Podoleński, physical education, health education, The Second Polish Republic, Jesuits, the youth, children 